\title{
A new ophiacanthid brittle star (Echinodermata, Ophiuroidea) from sublittoral crinoid and seagrass communities of late Maastrichtian age in the southeast Netherlands
}

\author{
Ben Thuy ${ }^{\text {Corresp., } 1}$, Lea Numberger-Thuy ${ }^{1}$, John WM Jagt ${ }^{2}$ \\ 1 Department of Palaeontology, Natural History Museum Luxembourg, Luxembourg City, Luxembourg \\ 2 Natuurhistorisch Museum Maastricht, Maastricht, The Netherlands \\ Corresponding Author: Ben Thuy \\ Email address: bthuy@mnhn.lu
}

A new species of brittle star, Ophiomitrella floorae, is recorded from the lower two meters of the Gronsveld Member (Maastricht Formation), of late Maastrichtian age (c. 66.7 Ma). These relatively fine-grained biocalcarenites reflect shallow-water deposition in a sheltered setting with a relatively firm sea floor and clear waters, under middle sublittoral and subtropical conditions. Associated echinoderm taxa comprise more robust, sturdy-plated ophiomusaid and ophiodermatid brittle stars and numerous bourgueticrinine sea lilies. The new brittle star described herein belongs to a family whose present-day members are predominantly restricted to bathyal depths. Its small size and the exceptional preservation of a single articulated specimen partially wrapped around the stalk of a bourgueticrinine suggest that $O$. floorae $n$. sp. was probably epizoic and specifically associated with stalked crinoids. 
1 A new ophiacanthid brittle star (Echinodermata,

2 Ophiuroidea) from sublittoral crinoid and seagrass

3 communities of late Maastrichtian age in the

4 southeast Netherlands

5

6

7

8

9

10

11

12

13

14

15

16

17

18

19

20

21

22

23

24

25

26

27

28

29

30

31

32

33

34

35

36

37

38

Ben Thuy ${ }^{1}$, Lea Numberger-Thuy ${ }^{1}$, John W.M. Jagt ${ }^{2}$

${ }^{1}$ Natural History Museum Luxembourg, Department of Palaeontology, 25, rue Münster, 2160

Luxembourg-city, Luxembourg

${ }^{2}$ Natuurhistorisch Museum Maastricht, De Bosquetplein 6-7 6211 KJ Maastricht, The

Netherlands.

Corresponding Author:

Ben Thuy ${ }^{1}$

Natural History Museum Luxembourg, Department of Palaeontology, 25, rue Münster, 2160

Luxembourg-city, Luxembourg

Email address: bthuy@mnhn.lu

\section{Abstract}

A new species of brittle star, Ophiomitrella floorae, is recorded from the lower two meters of the Gronsveld Member (Maastricht Formation), of late Maastrichtian age (c. 66.7 Ma). These relatively fine-grained biocalcarenites reflect shallow-water deposition in a sheltered setting with a relatively firm sea floor and clear waters, under middle sublittoral and subtropical conditions. Associated echinoderm taxa comprise more robust, sturdy-plated ophiomusaid and ophiodermatid brittle stars and numerous bourgueticrinine sea lilies. The new brittle star described herein belongs to a family whose present-day members are predominantly restricted to bathyal depths. Its small size and the exceptional preservation of a single articulated specimen partially wrapped around the stalk of a bourgueticrinine suggest that $O$. floorae n. sp. was probably epizoic and specifically associated with stalked crinoids.

\section{Introduction}

During recent decades, there has been a renewed interest in macrofossil assemblages from Upper Cretaceous (Campanian-Maastrichtian) strata in the type area of the Maastrichtian Stage (southeast Netherlands, northeast Belgium; Felder 1975a, b). This has resulted in the recovery of numerous previously unrecorded taxa, particularly amongst echinoderms. The former ENCIHeidelbergCement Group quarry at Sint-Pietersberg, south of the city of Maastricht (Figs. 1, 2),

PeerJ reviewing PDF | (2020:04:47350:2:0:NEW 7 Jul 2020) 
39 is a key locality in the area. Here the lower/middle portion of the Maastricht Formation

40 (Valkenburg, Gronsveld, Schiepersberg and Emael members) has yielded a range of brittlestar

41 taxa over recent years, amongst which sturdy-plated ophiomusaids and ophiodermatids

42 predominate (Jagt 1999c, d, 2000a). Smaller-sized species are much rarer and often occur as

43 dissociated ossicles of disc and arms only. An articulated specimen of an ophiacanthid partially

44 wrapped around the stalk of a bourgueticrinine crinoid from the lower Gronsveld Member (Jagt

45 2000a), in which obrution-related echinoderm Lagerstätten have been recorded between the St

46 Pieter and ENCI horizons (Fig. 3) (see Jagt et al. 1998; Jagt 1999b), provided the impetus for the

47 present note. In fact, it represents one of the very few known examples of an articulated

48 ophiacanthid fossil. Albeit illustrated and described in previous studies, it has not been

49 adequately assigned. Thanks to recent advances in ophiuroid phylogeny and in the systematic

50 assessment of dissociated skeletal plates (in particular lateral arm plates) and their

51 microstructures, it was possible to carry out a more detailed morphological analysis and attempt

52 a conclusive taxonomic interpretation of the material, thus filling a critical gap in the fossil

53 record of ophiacanthid brittle stars around the time of their demise at shallow depths (Thuy

54 2013).

55

56

57

58

59

Stratigraphical setting

The lower portion of the Maastricht Formation at the former ENCI-HeidelbergCement Group quarry comprises comparatively fine-grained, poorly indurated, pale yellow biocalcarenites with a diverse macrofossil content, in particular in the Valkenburg and Gronsveld members (Fig. 3). On the basis of recent cyclostratigraphical and chronostratigraphical age models for the type Maastrichtian (Keutgen 2018), the base of the Valkenburg Member (i.e., the contact between the Gulpen and Maastricht formations or Lichtenberg Horizon) can be dated at $66.8 \mathrm{Ma}$, and the base of the overlying Gronsveld Member (St Pieter Horizon) at 66.7 Ma. The latter horizon is thought to represent the early stages of a transgression from a relative lowstand during a tectonic inversion phase, while the overlying Gronsveld Member represents a relative highstand during tectonic relaxation, with the maximum flooding surface situated around the middle of this unit

68 (Schiøler et al. 1997).

69 In more general terms, referring to the area west of the River Maas (Meuse), the lowest unit of the Maastricht Formation, the Valkenburg Member, comprises poorly indurated, white-yellowish to yellowish-grey, fine- to coarse-grained biocalcarenites, with greyish brown flint nodules of varying sizes. The overlying Gronsveld Member consists of poorly indurated, white-yellowish to yellowish-grey, fine- to coarse-grained biocalcarenites, with small, light to dark greyish-brown flint nodules of varying sizes and shapes occurring in the lower part. In the higher portion they are arranged in more or less regular beds of light-grey to greyish blue nodules (Fig. 3). The lower portion of the Maastricht Formation has been considered to represent a gravelly

77 intrabiomicrosparite, with regional currents constant enough for horizontal displacement of 78 sediment particles over the entire platform, at sublittoral depths, judging from benthic 
79 foraminifera, ostracods and numerous plant fossils, including terrestrial forms such as conifers,

80 and sheltered from oceanic influence (Villain 1977; Jagt 1999a; Jagt \& Jagt-Yazykova 2012).

81 Frequent sediment reworking resulted in homogenisation over depths of a few decimetres,

82 leading to a relatively firm sea floor and clear waters. This setting has been interpreted as middle

83 sublittoral, under subtropical conditions and with sea grass communities (Liebau 1978; Jagt et al.

84 2019).

85 On evidence of index forms amongst coleoid cephalopods (Christensen et al. 2005; Jagt \& Jagt-

86 Yazykova 2019) and inoceramid bivalves (Jagt \& Jagt-Yazykova 2018), the lower portion of the

87 Maastricht Formation has been shown to be of late, though not latest, Maastrichtian age, thus

88 corroborating age assignments on the basis of dinoflagellates and calcareous nannoplankton (see

89 Schiøler et al. 1997; Keutgen 2018). All these biota allow correlation of these shallow-water

90 biocalcarenites along the fringes of Palaeozoic massifs (Fig. 4) with coeval levels in deeper-

91 water settings (white chalk, Schreibkreide) elsewhere in Europe (northern Germany, Denmark

92 and Poland).

93

94 Previous work on ophiuroids

95

96

97

98

99

100

101

102

103

104

105

106

107

Earlier records of late Maastrichtian echinoderms in the type area of the Maastrichtian Stage

have demonstrated several Lagerstätten, comprising mostly bourgueticrinine crinoids (and other comatulids associated; see Jagt et al. 1998; Jagt 1999b) as well as lesser numbers of echinoids (Jagt 2000b), asteroids (Jagt 2000c; Blake \& Jagt 2005; A.S. Gale \& J.W.M. Jagt, work in progress) and ophiuroids.

Brittle stars from the lower Gronsveld Member (Jagt 1999c, d, 2000a) include mostly semiarticulated individuals of the sturdy-plated Ophiomusium granulosum (Roemer, 1840) (= Ophiura (Aspidura) subcylindrica von Hagenow, 1840), Ophiotitanos serrata (Roemer, 1840) (= Ophiura parvisentis Spencer, 1908; Ophioglypha gracilis Valette, 1915) and Ophiopeza?

hagenowi (Wienberg Rasmussen, 1950) (see Wienberg Rasmussen 1950; Jagt 2000a; Ishida et al. 2018). Other taxa, such as Trichaster? ornatus (Wienberg Rasmussen, 1950)and Ophiothrix?

108 bongaertsi Kutscher \& Jagt, in Jagt, 2000, are much rarer and occur only as dissociated vertebrae

109

\section{0} and lateral arm plates, respectively (Jagt 2000a).

111 Jagt's (2000a) records of the ophiacanthid Ophiacantha? danica Wienberg Rasmussen, 1952

112 from the lower Gronsveld Member was based on a single, articulated individual in life position

113 around a crinoid stalk (NHMM K 3387), as well as a single isolated lateral arm plate (NHMM JJ

114 5104) obtained from the sieving residues of a bulk sediment sample from the same deposits. It is

115 this material which is revised herein. The material described herein was illustrated and/or

116 mentioned in previous studies (Jagt 2000a; Thuy 2013). For the purpose of the present

117 reassessment, dissociated lateral arm plates and the disc of the articulated specimen, detached

118 from the matrix, were mounted on a stub and gold-coated for scanning electron microscopy 
119 (LEO 1530 Gemini). Morphological terminologies follow Stöhr et al. (2012) for general skeletal 120 features, Thuy \& Stöhr (2011) for lateral arm plates and Hendler (2018) for the mouth skeleton.

121 We adopt the classification proposed by O'Hara et al. (2017, 2018). To denote the repositories of 122 the material described and illustrated here, the following abbreviations are used: NHMM, 123 Natuurhistorisch Museum Maastricht, Maastricht, the Netherlands; SMNH, Swedish Museum of 124 Natural History, Stockholm, Sweden; MNHN, Muséum national d'Histoire naturelle, Paris, 125 France.

126 The electronic version of this article in Portable Document Format (PDF) will represent a 127 published work according to the International Commission on Zoological Nomenclature (ICZN), 128 and hence the new names contained in the electronic version are effectively published under that 129 Code from the electronic edition alone. This published work and the nomenclatural acts it 130 contains have been registered in ZooBank, the online registration system for the ICZN. The 131 ZooBank LSIDs (Life Science Identifiers) can be resolved and the associated information viewed 132 through any standard web browser by appending the LSID to the prefix http://zoobank.org/.The 133 LSID for this publication is: urn:lsid:zoobank.org:pub:9BE69BFD-69FE-4671-BC94134 0DF402806A75. The online version of this work is archived and available from the following 135 digital repositories: PeerJ, PubMed Central and CLOCKSS.

136

\section{Results}

138 Systematic palaeontology

139

Class Ophiuroidea Gray, 1840

141 Subclass Myophiuroidea Matsumoto, 1915

142 Infraclass Metophiurida Matsumoto, 1913 (crown-group of Ophiuroidea)

143 Superorder Ophintegrida O'Hara, Hugall, Thuy, Stöhr \& Martynov, 2017

144 Order Ophiacanthida O'Hara, Hugall, Thuy, Stöhr \& Martynov, 2017

145 Suborder Ophiacanthina O'Hara, Hugall, Thuy, Stöhr \& Martynov, 2017

146 Family Ophiacanthidae Ljungman, 1867

147 Genus Ophiomitrella Verrill, 1899

148

149

150

151

152

153

154

155

156

Ophiomitrella floorae n. sp.

Fig. 5A-C

Etymology: Named after Floor Jansen, lead singer of the Finnish band Nightwish in recognition of her long-standing career in metal, her general interest in all things (palaeo)biological and her and the band's use of fossils for artwork (Metal Mike, 2020).

Type locatipe: NHMM JJ 5104

157 Type locality and stratum: lower Gronsveld Member (Maastricht Formation; St Pieter and ENCI 158 horizons) at the former ENCI-HeidelbergCement Group quarry, Maastricht, the Netherlands. 
159

160

161

162

163

164

165

166

167

168

169

170

171

172

173

174

175

176

177

178

179

180

181

182

183

184

185

186

187

188

189

190

191

192

193

194

195

196

197

198

Paratype: NHMM K 3387

Note that most of the specimens cited as Ophiacantha? danica in Jagt (2000a) have subsequently been re-assigned to Ophiogaleus danicus by Thuy (2013) and Ophiotreta striata (Kutscher \&

Jagt, in Jagt, 2000). Of the remaining specimens, only the articulated disc of Jagt's (2000a) plate 2, figure 7 (NHMM K 3387) and the lateral arm plate of Thuy's (2013) figure 32-2 (NHMM JJ 5104) are unambiguously assignable to the species described herein. All other specimens either are too poorly preserved for a conclusive assessment or belong to a different species.

Diagnosis: Small species of Ophiomitrella with high lateral arm plates showing up to eight large spine articulations and a very weak and fine vertical striation; large, wide adoral shields; two to three large, conical oral papillae sensu lato and a single large, conical ventralmost tooth.

Description of holotype: NHMM JJ 5104 (Fig. 5A-B) is a dissociated proximal lateral arm plate, almost two times taller than long; dorsal edge concave due to a strong constriction; distal edge strongly and regularly convex; proximal edge weakly concave and devoid of spurs; ventral portion of lateral arm plate not protruding. Outer surface with finely meshed stereom and a very weak, fine vertical striation close to ridge of spine articulations. Eight large, ear-shaped spine articulations on a strongly elevated distal portion of lateral arm plate; row of spine articulations proximally bordered by thick, conspicuous, straight ridge; spine articulations each consisting of large muscle opening enclosed by dorsal and ventral lobes forming round, continuous ring, and separated from smaller nerve opening by well-developed sigmoidal fold; weak dorsalward increase in size of spine articulations and distance between them. Ventral edge of lateral arm plate oblique; tentacle notch invisible in external view; row of spine articulations protruding ventralwards. Inner side of lateral arm plate with large, well-defined vertebral articulation shaped like slightly rotated digit one with an expanded nose; tentacle notch small but well defined, distally bordering thickened ventral edge of lateral arm plate; poorly defined vertical furrow running parallel to row of spine articulations but presence of perforations ambiguous due to insufficient preservation.

The paratype (NHMM K 3387, Fig. 5C) is an articulated skeleton with an arm wrapped around a bourgueticrinine stalk; the proximal arm portions show lateral arm plates similar to the holotype; the disc is poorly preserved due to coarse recrystallisation, blurring all details on the dorsal side; ventral side of the disc preserving a few details of the skeleton; four arm bases preserved intact, showing strongly recrystallised lateral and ventral arm plates and ventral arm spines; lateral arm plates identical to holotype; ventral arm plates with a strongly convex distal edge, deeply incised lateral edges and a pointed proximal tip; arm spines at least as long as one arm segment; adoral shields large and wide; two to three large, conical oral papillae sensu lato and a large, conical ventralmost tooth.

\section{Discussion}


199 The material described herein unambiguously belongs to the family Ophiacanthidae as defined 200 by O'Hara et al. (2018) on account of the large, ear-shaped spine articulations proximally 201 bordered by a sharply defined ridge, the non-protruding ventral portion of the lateral arm plates, 202 and the shape of the ridge on the inner side of the lateral arm plates. Within this family, several 203 clades have been resolved using molecular evidence (O'Hara et al. 2017), but only very few 204 agree with previously defined genera (e.g., Ophioplinthaca). Most traditional ophiacanthid

205

206

207

208

209

210

211

212

213

214

215

216

217

218

219

220

221

222

223

224

225

226

227

228

229

230

231

232

233

234

235

236

237

238 genera are poly- or paraphyletic, challenging the diagnostic value of the characters used to define these taxa (O'Hara et al. 2017). In contrast, patterns in lateral arm plate morphology seem to agree with molecular evidence in many aspects (O'Hara et al. 2014; Thuy \& Stöhr 2016), corroborating that lateral arm plates can be used to constrain the position of a species within the family Ophiacanthidae (Thuy 2013).

In the light of this conclusion, and due to the poor preservation of the single articulated individual, we have chosen the dissociated proximal lateral arm plate as the holotype of the new species. Microstructural details of the lateral arm plate morphology put the specimens closest to the ophiacanthid genera Ophiomitrella and Ophiacantha. The mouth skeleton of the paratype specimen corroborates this position. The development of the vertical striation on the outer surface ornamentation of the lateral arm plates, the shape of the ridge proximally bordering the row of spine articulations, and the shape of the vertebral articulation on the inner side of the lateral arm plate excludes all other genera assigned to the family Ophiacanthidae as defined by O'Hara et al. 2018. Both Ophiomitrella and Ophiacantha, as currently understood, are polyphyletic and require revision (O'Hara et al. 2018), hampering a clear-cut genus-level assignment. The type species of Ophiacantha, O. bidentata (Bruzelius, 1805), differs from the specimens described herein in having a more expanded vertical striation on the outer surface and a row of spine articulations that does not protrude ventralwards. We therefore preclude assignment to Ophiacantha and favour Ophiomitrella instead, although it must be stressed that the type species of the genus, Ophiomitrella laevipellis (Lyman, 1883), has not been genetically sequenced nor morphologically dissected as yet because it is known only from very valuable historical samples, rarely represented in museum collections.

Within the three clades resolved by molecular evidence and containing the recent species of Ophiomitrella (O'Hara et al. 2017), the specimens described herein show closest similarities to the species of the clade that contains Ophiomitrella granulosa (Lyman, 1878) (Fig. 5D-G) and O. mensa O'Hara \& Stöhr, 2006. In members of the second clade, in particular Ophiomitrella conferta (Koehler, 1922) and O. clavigera (Ljungman, 1865), the vertebral articulation looks more like a digit 1 and lacks the expanded nose. Comparison with members of the third clade of Ophiomitrella species, e.g. O. stellifera Matsumoto, 1917, was hampered by the lack of information on the microstructures of the lateral arm plate. Thus, as long as the systematic position of the type species is unresolved, assignment to Ophiomitrella is tentative and should merely underline the close relationship with $O$. granulosa.

The material described herein differs from previously recorded fossils assigned to Ophiomitrella in the higher number of spine articulations and the finer, less pronounced vertical striation on the 
239

240

241

242

243

244

245

246

247

248

249

250

251

252

253

254

255

256

257

258

259

260

261

262

263

264

265

266

267

268

269

270

271

272

273

274

275

276

277

278

outer surface of the lateral arm plates (Thuy 2013). Assignment to a Recent species is precluded by the stratigraphical age of the fossils, implying an implausibly long range; we therefore assign the material described herein to a new species. Notwithstanding the above-mentioned uncertainties in the definition of the genus, $O$. floorae n. sp. fills an important stratigraphic gap between the previously published records of Ophiomitrella from the Middle Jurassic (Thuy 2013) and the morphologically similar living species of the genus.Recent members of Ophiomitrella, and of the family Ophiacanthidae in general, predominantly live at deep sublittoral to bathyal depths, i.e., between 150 and 2,000 m, (O'Hara \& Stöhr 2006; O'Hara et al. 2017). Thus, the discovery of Ophiomitrella floorae n. sp. aligns with the co-occurring ophiomusaid brittle stars and bourgueticrinine sea lilies in belonging to groups once common and widespread at shallow depths but nowadays restricted to deeper waters (e.g., Thuy et al. 2012). Their occurrence at middle sublittoral paleo-depths during the late Maastrichtian is a relict of their mid-Mesozoic occurrence in shallow waters (Thuy et al. 2012; Thuy \& Meyer 2013; Thuy 2013).

Ophiomitrella floorae is one of the first fossil ophiuroids shown to be associated with stalked crinoids. The exceptional discovery of an articulated individual partially wrapped around the stalk of a bourgueticrinine (Jagt 2000a) (Fig. 6) could imply that the ophiuroid lived on the crinoid, with the mouth facing the stalk. The small size and general morphology of Ophiomitrella floorae $\mathrm{n}$. sp. conforms to an epizoic lifestyle as commonly observed in living congeners (e.g., O’Hara \& Stöhr 2006). However, since the specimen is only partially wrapped around the stalk, we cannot entirely rule out the possibility that the ophiuroid and the crinoid were washed together, with the crinoid accidentally "grabbing" the crinoid stalk before burial. The only unambiguous example of an ophiuroid-crinoid association in the fossil record is the Paleozoic stem ophiuroid Onychaster that lived epizoically on stalked crinoids (Hotchkiss \& Glass 2012), often found tightly wrapped around the stem or cup of the associated crinoids Living ophiuroids epizoic on rod-shaped hosts like corals generally extend several arms into the water column for feeding and are only tightly coiled around their host when resting (e.g., Steward \& Mladenov 1994). Also, ophiuroids dislodged from their substrate, e.g. by strong currents, tend to coil their arms around the disc (Emson \& Wilkie 1982) for more rapid sinking. Thus, it seems likely that $O$. floorae n. sp. lived epizoic on bourgueticrinine sea lilies, although we cannot rule out an accidental intertwining of the arms as a result of obrution and/or an attempt of the ophiuroid to free itself after having been smothered.

\section{Conclusions}

The case of Ophiomitrella floorae n. sp. demonstrates that a significant portion of ophiuroid palaeo-biodiversity is easily overlooked. Due to the small size and delicate skeleton of the species, it was much less likely to be noticed than the larger, sturdy-plated and therefore more conspicuous co-occurring ophiomusaid and ophiodermatid brittle stars. The single articulated

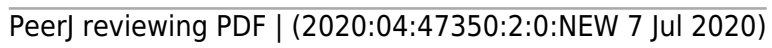


279

280

281

282

283

284

285

286

287

288

289

290

291

292

293

294

295

296

297

298

299

300

301

302

303

304

305

306

307

308

309

310

311

312

313

314

315

316

317

individual was previously too poorly preserved to allow for unambiguous species-level identification (Jagt 2000a). It was only thanks to co-occurring dissociated lateral arm plates that the species could be described, thus underscoring the importance of microfossils in assessing the paleo-biodiversity of taxa with multi-element skeletons such as brittle stars.

\section{Acknowledgements}

One of us (JWMJ) thanks the management of the former ENCI-HeidelbergCement Group quarry (Maastricht) for permission to do fieldwork at their grounds over recent decades, and fellow palaeontologists Mart Deckers, Rudi Dortangs and Marcel Kuypers for support during fieldwork and for donation of echinoderm material. We thank Mart Deckers for providing the photograph used in Figure 2, and Sabine Stöhr for providing the scanning electron images used in Figure 5 (F-G). We furthermore thank the reviewers whose comments improved an earlier version of this manuscript.

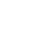

\section{References}

Blake, D.B. \& Jagt, J.W.M., 2005. New latest Cretaceous and earliest Paleogene asteroids (Echinodermata) from The Netherlands and Denmark and their palaeobiological significance. Bulletin de l'Institut royal des Sciences naturelles de Belgique, Sciences de la Terre, 75, 183200.

Bruzelius, N., 1805. Dissertatio sistens species cognitas asteriarum, quamr. sub praesidio A.J. Retzii. exhibet N. Bruzelius. 1-37. Lundae (formerly known as Retzius, A.J.).

Christensen, W.K., Schmid, F. \& Schulz, M.-G., 2005. Belemnitella from the Upper

Maastrichtian of Hemmoor, northwest Germany. Geologisches Jahrbuch, A157 (for 2004), 2367.

Emson, R.H. \& Wilkie, I.C., 1982. The arm-coiling response of Amphipholis squamata (Delle Chiaje), in Lawrence, J.M. (ed.) Echinoderms: Proceedings of the International Conference, Tampa Bay, September 1981, Balkema, Rotterdam, 11-18.

Felder, W.M., 1975a. Lithostratigraphische Gliederung der Oberen Kreide in Süd-Limburg (Niederlande) und den Nachbargebieten. 1. Teil: Der Raum westlich der Maas, Typusgebiet des' Maastricht'. Publicaties van het Natuurhistorisch Genootschap in Limburg, 24, 1-43. 
318 Felder, W.M., 1975b. Lithostratigrafie van het Boven-Krijt en het Dano-Montien in Zuid319 Limburg en het aangrenzende gebied, 63-72. In: Zagwijn, W.H. \& Van Staalduinen, C.J. (eds.).

320 Toelichting bij geologische overzichtskaarten van Nederland. Rijks Geologische Dienst, 321 Haarlem.

322

323 Felder, W.M. \& Bosch, P.W., 1998. Geologie van de St. Pietersberg bij Maastricht. Grondboor

324 325

326

327

328

329

330

331

332

333

334

335

336

337

338

339

340

341

342

343

344

345

346

347

348

349

350

351

352

353

354

355

356

357

\& Hamer, 52(3) [Limburgnummer 9A: Geologie van de St. Pietersberg], 53-63.

Gray, J.E., 1840. Room II: Synopsis of the contents of the British Museum. British Museum, London, 57-65.

Hagenow, F. von, 1840. Monographie der Rügen'schen Kreideversteinerungen. Abtheilung 2. Radiarien und Annulaten nebst Nachträge zur 1. Abtheilung. Neues Jahrbuch für Mineralogie, Geognosie, Geologie und Petrefaktenkunde, 1840, 631-672.

Hendler, G., 2018. Armed to the teeth: a new paradigm for the buccal skeleton of brittle stars (Echinodermata: Ophiuroidea). Contributions in Science, 526, 189-311.

Hotchkiss, F.H.C. \& Glass, A., 2012. Observations on Onychaster Meek \& Worthen, 1868 (Ophiuroidea: Onychasteridae) (Famennian - Visean age) In: Kroh, A. \& Reich, M. (Eds.) Echinoderm Research 2010: Proceedings of the Seventh European Conference on Echinoderms, Göttingen, Germany, 2-9 October 2010. Zoosymposia, 7, 121-138.

Ishida, Y., Thuy, B., Fujita, T., Kadokawa, M., Ikegami, N. \& Numberger-Thuy, L.D., 2018. A new species of Stegophiura (Ophiuroidea, Ophiopyrgidae) from the mid-Cretaceous of southern Japan. Swiss Journal of Palaeontology, 137, 319-325.

Jagt, J.W.M., 1999a. Late Cretaceous-Early Palaeogene echinoderms and the K/T boundary in the southeast Netherlands and northeast Belgium - Part 1: Introduction and stratigraphy. Scripta Geologica, 116, 1-57.

Jagt, J.W.M., 1999b. Late Cretaceous-Early Palaeogene echinoderms and the K/T boundary in the southeast Netherlands and northeast Belgium - Part 2: Crinoids. Scripta Geologica, 116, 59255.

Jagt, J.W.M., 1999c. An overview of Late Cretaceous and Early Palaeogene echinoderm faunas from Liège-Limburg (Belgium, The Netherlands). In: Dhondt, A.V. \& Alekseev, A.S. (eds). D.P. Naidin Festschrift (INTAS 94-1414). Bulletin de l'Institut royal des Sciences naturelles de Belgique, Sciences de la Terre, 69 (Suppl. A), 103-118.

Peerj reviewing PDF | (2020:04:47350:2:0:NEW 7 Jul 2020) 
358

359

360

361

362

363

364

365

366

367

368

369

370

371

372

373

374

375

376

377

378

379

380

381

382

383

384

385

386

387

388

389

390

391

392

393

394

395

396

Jagt, J.W.M., 1999d. Ophiuroid diversity in the type area of the Maastrichtian Stage. In:

Vergoossen, J.M.J. \& Lambers, P.H. (eds). Actual paleontology - paleontology in action: a tribute to Bert Boekschoten. Geologie en Mijnbouw, 78, 197-206.

Jagt, J.W.M., 2000a. Late Cretaceous-Early Palaeogene echinoderms and the K/T boundary in the southeast Netherlands and northeast Belgium - Part 3: Ophiuroids. With a chapter on: Early Maastrichtian ophiuroids from Rügen (northeast Germany) and Møn (Denmark) by Manfred Kutscher \& John W.M. Jagt. Scripta Geologica, 121, 1-179.

Jagt, J.W.M., 2000b. Late Cretaceous-Early Palaeogene echinoderms and the K/T boundary in the southeast Netherlands and northeast Belgium - Part 4: Echinoids. Scripta Geologica, 121, $181-375$.

Jagt, J.W.M., 2000c. Late Cretaceous-Early Palaeogene echinoderms and the K/T boundary in the southeast Netherlands and northeast Belgium - Part 5: Asteroids. Scripta Geologica, 121, 377-503.

Jagt, J.W.M., Deckers, M., Donovan, S.K., Fraaije, R., Goolaerts, S., Van der Ham, R., Hart, M.B., Jagt-Yazykova, E.A., Van Konijnenburg-van Cittert, J. \& Renkens, S., 2019. Latest Cretaceous storm-generated sea grass accumulations in the Maastrichtian type area, the Netherlands - preliminary observations. Proceedings of the Geologists' Association, 130, 590598.

Jagt, J.W.M., Donovan, S.K., Deckers, M.J.M., Dortangs, R.W., Kuypers, M.M.M. \& Veltkamp, C.J., 1998. The Late Maastrichtian bourgueticrinid crinoid Dunnicrinus aequalis (d'Orbigny, 1841) from The Netherlands and Belgium. Bulletin de l'Institut royal des Sciences naturelles de Belgique, Sciences de la Terre, 68, 129-154.

Jagt, J.W.M., Deckers, M.J.M., De Leebeeck, M., Donovan, S.K. \& Nieuwenhuis, E., 2020. Episkeletozoans and bioerosional ichnotaxa on isolated bones of Late Cretaceous mosasaurs and cheloniid turtles from the Maastricht area, the Netherlands. Geologos, 26, 39-49.

Jagt, J.W.M. \& Jagt-Yazykova, E.A., 2012. Stratigraphy of the type Maastrichtian - a synthesis. In: Jagt, J.W.M., Donovan, S.K. \& Jagt-Yazykova, E.A. (eds). Fossils of the type Maastrichtian (Part 1). Scripta Geologica Special Issue, 8, 5-32.

Jagt, J.W.M. \& Jagt-Yazykova, E.A., 2018. Stratigraphical ranges of tegulated inoceramid bivalves in the type area of the Maastrichtian Stage (Belgium, the Netherlands). In: JagtYazykova, E.A., Jagt, J.W.M. \& Mortimore, R.N. (eds). Advances in Cretaceous palaeontology 
397

398

399

400

401

402

403

404

405

406

407

408

409

410

411

412

413

414

415

416

417

418

419

420

421

422

423

424

425

426

427

428

429

430

431

432

433

434

435

436

and stratigraphy - Christopher John Wood Memorial Volume. Cretaceous Research, 87, 385394.

Jagt, J.W.M. \& Jagt-Yazykova, E.A., 2019. Late Cretaceous and Cenozoic cephalopods from the southern North Sea Basin: stocktaking and future directions. Vita Malacologica, 18, 1-33.

Keutgen, N., 2018. A bioclast-based astronomical timescale for the Maastrichtian in the type area (southeast Netherlands, northeast Belgium) and stratigraphic implications: the legacy of P.J. Felder. Netherlands Journal of Geosciences, 97, 229-260.

Koehler, R., 1922. Echinodermata: Ophiuroidea. Australasian Antarctic Expedition 1911-1914. Scientific Report Series C., 8(2), 5-98, pls 76-90.

Kutscher, M. \& Jagt, J.W.M., 2000. Early Maastrichtian ophiuroids from Rügen (northeast Germany) and Møn (Denmark). In: Jagt J.W.M. 2000. Late Cretaceous-Early Palaeogene echinoderms and the K/T boundary in the southeast Netherlands and the northeast Belgium Part 3: Ophiuroids. Scripta Geologica, 121, 45-107.

Liebau, A., 1978. Paläobathymetrische und paläoklimatische Veränderungen im Mikrofaunenbild der Maastrichter Tuffkreide. Neues Jahrbuch für Geologie und Paläontologie Abhandlungen, 157, 233-237.

Ljungman, A.V., 1865. Tillägg till kännedom af Skandinaviens Ophiurider. Öfversigt af Kongeliga Vetenskaps-Akademiens Förhandlingar 1863, 21, 359-367, pl. 15.

Ljungman, A.V., 1867. Ophiuroidea viventia huc usque cognita enumerat. Öfversigt af Kongeliga Vetenskaps-Akademiens Förhandlingar 1866, 23, 303-336.

Lyman, T., 1878. Ophiuridae and Astrophytidae of the "Challenger" expedition. Part I. Bulletin of the Museum of Comparative Zoology at Harvard College, Cambridge, Mass. 5, 65-168, 10 pls.

Lyman, T., 1883. Reports on the results of dredging, under the supervision of Alexander Agassiz, in the Caribbean Sea (1878-79), and on the east coast of the United States, during the summer of 1880, by the U.S. coast survey steamer "Blake", commander J.R. Bartlett, U.S.N., commanding. XX.- Report on the Ophiuroidea. Bulletin of the Museum of Comparative Zoology at Harvard. 10, 227-287.

Matsumoto, H., 1913. Evolutionary history of the class Ophiuroidea and a note on the new classification of the class. Zoological Magazine, 25, 521-527. 
437

438

439

440

441

442

443

444

445

446

447

448

449

450

451

452

453

454

455

456

457

458

459

460

461

462

463

464

465

466

467

468

469

470

471

472

473

474

475

Matsumoto, H., 1915. A new classification of the Ophiuroidea: with descriptions of new genera and species. Proceedings of the Academy of Natural Sciences of Philadelphia, 67, 43-92.

Matsumoto, H., 1917. A monograph of Japanese Ophiuroidea, arranged according to a new classification. Journal of the College of Science, Imperial University, Tokyo, 38, 1-408.

Metal Mike, 2020. Floor Jansen. Via bergen en dalen naar de top. Aardschok (Internationaal Metal Magazine), 41, 12-21 (www.aardschok.com).

O’Hara, T.D., Hugall, A.F., Thuy, B. \& Moussalli, A., 2014. Phylogenomic resolution of the class Ophiuroidea unlocks a global microfossil record. Current Biology, 24, 1874-1879. https://doi.org/10.1016/j.cub.2014.06.060.

O’Hara, T.D., Hugall, A.F., Thuy, B., Stöhr, S. \& Martynov, A.V., 2017. Restructuring higher taxonomy using broad-scale phylogenomics: the living Ophiuroidea. Molecular Biology and Evolution, 107, 415-430 DOI 10.1016/j.ympev.2016.12.006.

O’Hara, T.D. \& Stöhr, S., 2006. Deep water Ophiuroidea (Echinodermata) of New Caledonia: Ophiacanthidae and Hemieuryalidae, in Richer de Forges, B \& Justine, J.-L. (eds), Tropical Deep-Sea Benthos, volume 24. Mémoires du Muséum national d'Histoire naturelle, 193, 33-141.

O’Hara, T.D., Stöhr, S., Hugall, A.F., Thuy, B. \& Martynov, A., 2018. Morphological diagnoses of higher taxa in ophiuroidea (Echinodermata) in support of a new classification. European Journal of Taxonomy, 416, 1-35.

Roemer, F.A., 1840-1841. Die Versteinerungen des norddeutschen Kreidegebirges, iv + 1-48, 49-145. Hahn'sche Hofbuchhandlung, Hannover.

Schiøler, P., Brinkhuis, H., Roncaglia, L. \& Wilson, G.J., 1997. Dinoflagellate biostratigraphy and sequence stratigraphy of the type Maastrichtian (Upper Cretaceous), ENCI Quarry, The Netherlands. Marine Micropaleontology, 31, 65-95.

Spencer, W.K., 1905-1908. A monograph on the British fossil Echinodermata from the Cretaceous formations, 2. The Asteroidea and Ophiuroidea. Monograph of the Palaeontographical Society London, 67-90 (1905), 91-132 (1907), 133-138 (1908).

Steward, B. \& Mladenov, P.V., 1994. Aspects of reproduction and anatomy of the euryalinid snake star Astrobrachion constrictum. In: David, B., Guille, A., Féral, J.P. \& Roux, M. (eds),

Peer) reviewing PDF | (2020:04:47350:2:0:NEW 7 Jul 2020) 
476 Echinoderms through Time, Proceedings of the 8th International Echinoderm Conference, Dijon,

477 France., Balkema, Rotterdam, 491-497.

478

479 Stöhr, S., O’Hara, T.D. \& Thuy, B., 2012. Global diversity of brittle stars (Echinodermata:

480 Ophiuroidea). PLoS ONE, 7(3), e31940 DOI 10.1371/journal.pone.0031940.

481

482

Thuy, B., 2013. Temporary expansion to shelf depths rather than an onshore-offshore trend: the

483 shallow-water rise and demise of the modern deep-sea brittle star family Ophiacanthidae

484

485

486 (Echinodermata: Ophiuroidea). European Journal of Taxonomy, 48, 1-242.

487

488

489

490

491

492

493

494

495

496

497

498

499

500

501

502

503

504

505

506

507

508

509

510

511

512

513

514 Wienberg Rasmussen, H., 1952. Cretaceous Ophiuroidea from Germany, Sweden, Spain and

515 New Jersey. Meddelelser fra Dansk Geologisk Forening, 12 (for 1951), 47-57. 2012. Ancient Origin of the Modern Deep-Sea Fauna. PLoS ONE, 7(10), e46913. doi:10.1371/journal.pone.0046913.

Thuy, B. \& Meyer, C.A., 2013. The pitfalls of extrapolating modern depth ranges to fossil assemblages: new insights from Middle Jurassic brittle stars (Echinodermata: Ophiuroidea) from Switzerland. Swiss Journal of Palaeontology, 132, 5-21.

Thuy, B. \& Stöhr, S., 2011. Lateral arm plate morphology in brittle stars (Echinodermata: Ophiuroidea): new perspectives for ophiuroid micropalaeontology and classification. Zootaxa, 3013(1), 1-47 DOI 10.11646/zootaxa.3013.1.1.

Thuy, B. \& Stöhr, S., 2016. A new morphological phylogeny of the Ophiuroidea (Echinodermata) accords with molecular evidence and renders microfossils accessible for cladistics. PLoS One, 11 (5), e0156140.https://doi.org/10.1371/journal.pone.0156140

Valette, A., 1915. Les ophiures de la craie des environs de Sens. Bulletin de la Société des Sciences historiques et naturelles de l'Yonne, 68, 125-150.

Verrill, A.E., 1899. Report on the Ophiuroidea collected by the Bahama expedition in 1893. Bulletin from the Laboratories of Natural History of the State University of Iowa, 5, 1-86.

Villain, J.-M., 1977. Le Maastrichtien dans sa région type (Limbourg, Pays-Bas). Étude stratigraphique et micropaléontologique. Palaeontographica, A157, 1-87.

Wienberg Rasmussen, H., 1950. Cretaceous Asteroidea and Ophiuroidea with special reference to the species found in Denmark. Danmarks geologiske Undersøgelse, 77, 1-134.

Thuy, B., Gale, A.S., Kroh, A., Kucera, M., Numberger-Thuy, L.D., Reich, M. \& Stöhr, S.,

PeerJ reviewing PDF | (2020:04:47350:2:0:NEW 7 Jul 2020) 
516

517

518

519

520

521

522

523

524

525

526

527

528

529

530

531

532

533

534

535

536

537

538

539

540

541

542

543

544

545

546

547

548

549

550

551

552

553

554

Figure 1. Map of southern Limburg and contiguous areas in Belgium and Germany, representing the extended type area of the Maastrichtian Stage and showing the location of the former ENCIHeidelbergCement Group quarry (modified from Jagt et al., 2020).

Figure 2. The northeast corner of the former ENCI-HeidelbergCement Group quarry (Maastricht), looking southwest (Spring 2019); the level with tyre tracks corresponds roughly to the lower Gronsveld Member (St Pieter and ENCI horizons; see Fig. 3; photograph by M.J.M. Deckers).

Figure 3. Litholog of the lower Maastricht Formation (modified from Felder \& Bosch, 1998), with the St Pieter and ENCI horizons in the lower part of the Gronsveld Member. The arrow in the higher part of that unit refers to one of the more spectacular storm levels in the section (for details, see Jagt et al., 2019).

Figure 4. Reconstruction of oceans, epicontinental seas and land masses during the late Late Cretaceous (c. 75 Ma; C2012 Colorado Plateau Geosystems Inc.).

Figure 5. Ophiomitrella floorae n. sp., from the lower Gronsveld Member (Maastricht Formation; St Pieter and ENCI horizons) at the former ENCI-HeidelbergCement Group quarry, Maastricht, the Netherlands. A-B: holotype (NHMM JJ 5104), dissociated proximal lateral arm plate in external (A) and internal (B) views; C: paratype (NHMM K 3387), articulated disc with basal arm segments in ventral view. Ophiomitrella granulosa Recent, as a close living relative of O. floorae n. sp. D-E: proximal lateral arm plate (SMNH-121224) in external (D) and internal (E) views; F-G: complete individual (MNHNEcOs22429) in dorsal view (F) and with detail of ventral disc skeleton $(\mathrm{G})$. Abbreviations: AOS: adoral shield; AS: arm spine; do: dorsal; LAP: lateral arm plate; MO: muscle opening; NO: nerve opening; OS: oral shield; pr: proximal; R: ridge; T: tooth; VA: vertebral articulation; VAP: ventral arm plate. Scale bars equal 0,25 $\mathrm{mm}$ in A-B and D-E, and $1 \mathrm{~mm}$ in C and F-G. Scanning electron microscope images of Figs. F-G by Sabine Stöhr.

Figure 6. Ophiomitrella floorae n. sp., from the lower Gronsveld Member (Maastricht Formation; St Pieter and ENCI horizons) at the former ENCI-HeidelbergCement Group quarry, Maastricht, the Netherlands. Paratype (NHMM K 3387); A: articulated skeleton before removal of the disc and proximal arm segments for scanning electron microscopy; B: detail of an arm in dorsal view. Abbreviations: DAP: dorsal arm plate; LAP: lateral arm plate. Scale bars equal 1 $\mathrm{mm}$.

PeerJ reviewing PDF | (2020:04:47350:2:0:NEW 7 Jul 2020) 
Figure 1

Locality map

Map of southern Limburg and contiguous areas in Belgium and Germany, representing the extended type area of the Maastrichtian Stage and showing the location of the former ENClHeidelbergCement Group quarry (modified from Jagt et al., 2020).

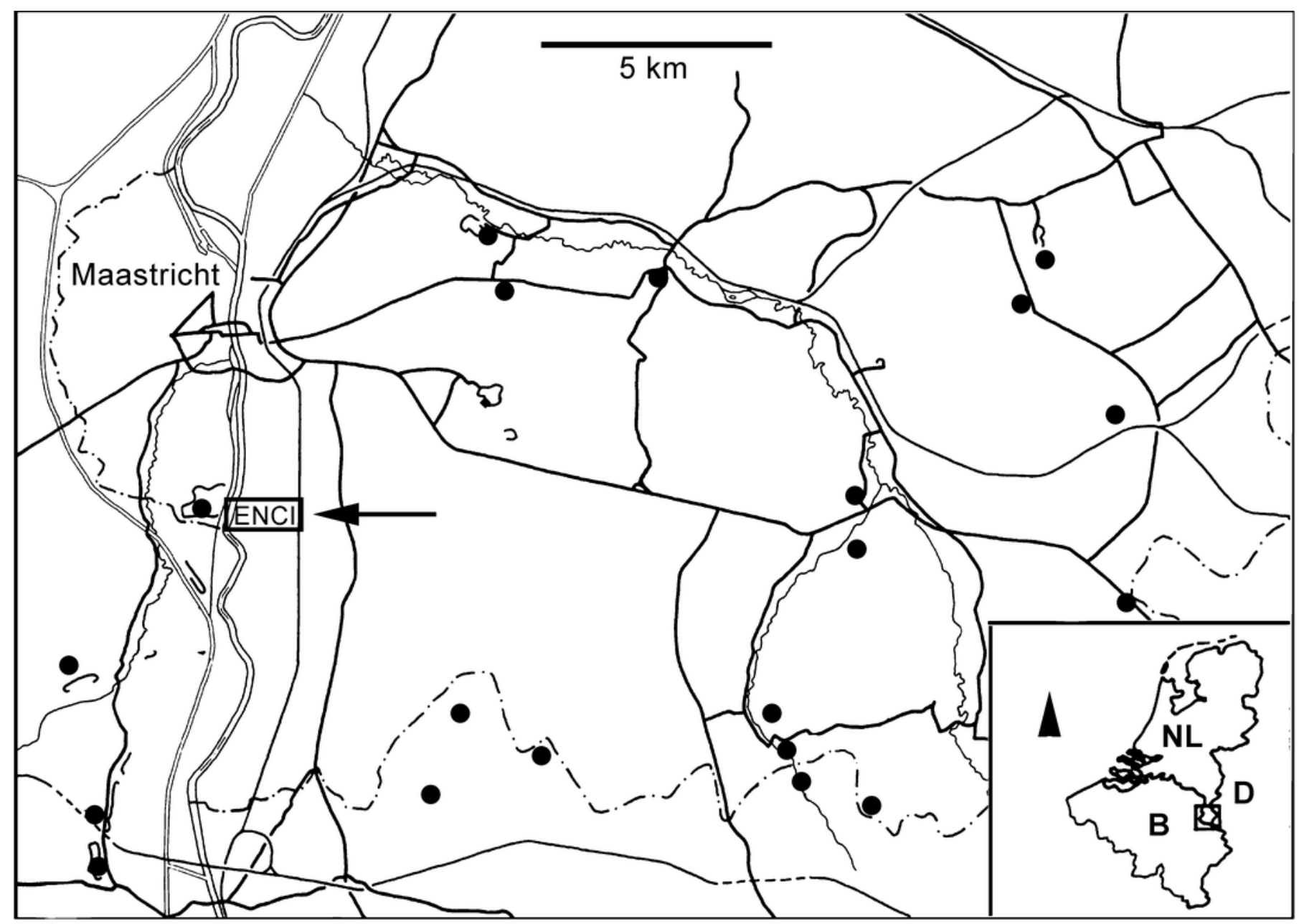




\section{Figure 2}

ENCl-HeidelbergCement Group quarry.

The northeast corner of the former ENCl-HeidelbergCement Group quarry (Maastricht), looking southwest (Spring 2019); the level with tyre tracks corresponds roughly to the lower Gronsveld Member (St Pieter and ENCI horizons; see Fig. 3; photograph by M.J.M. Deckers).

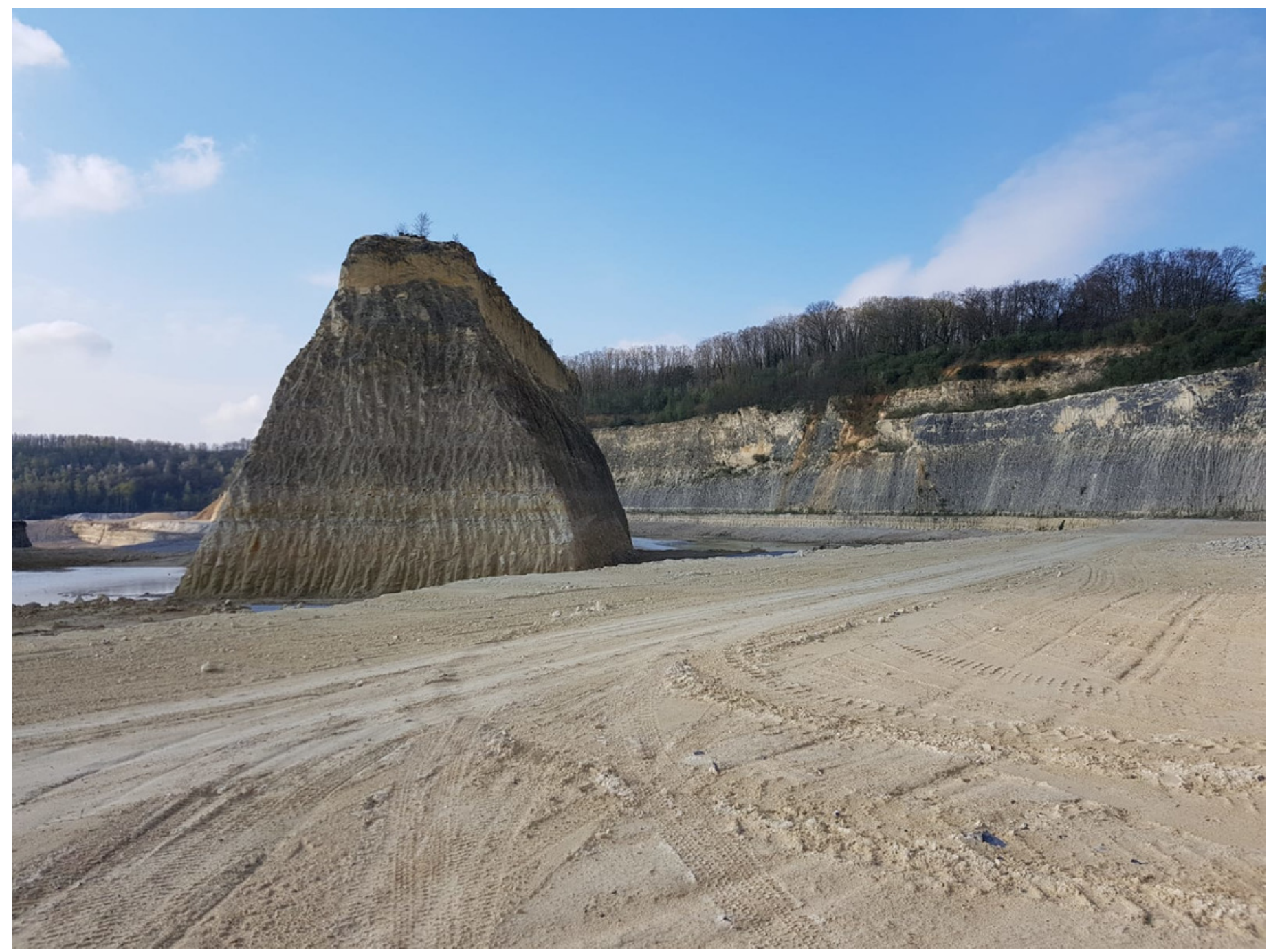


Figure 3

Litholog of the lower Maastricht Formation.

Log (modified from Felder \& Bosch, 1998), with the St Pieter and ENCI horizons in the lower part of the Gronsveld Member. The arrow in the higher part of that unit refers to one of the more spectacular storm levels in the section (for details, see Jagt et al., 2019). 


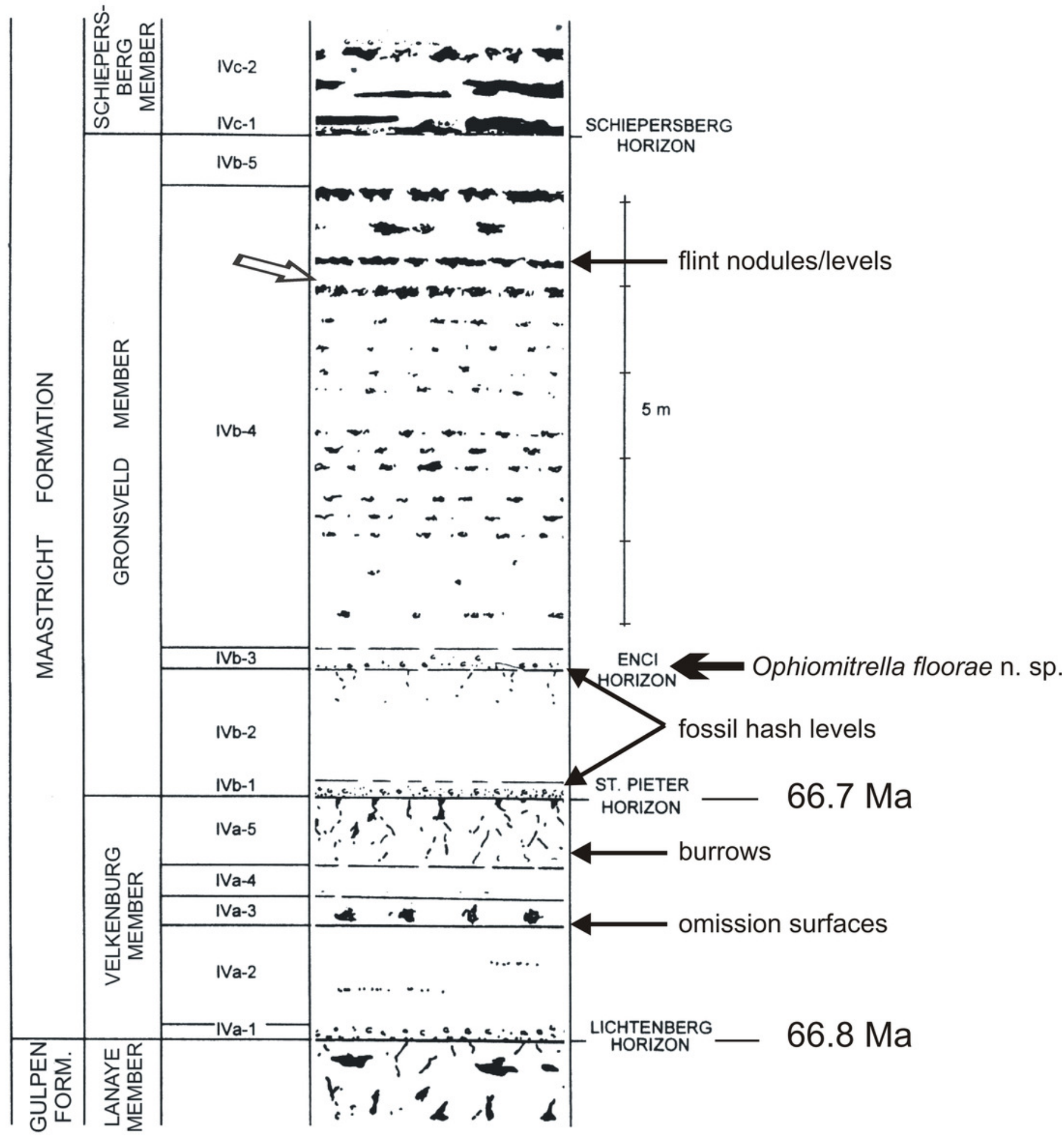


Figure 4

Plaeogeographical map.

Reconstruction of oceans, epicontinental seas and land masses during the late Late Cretaceous (c. 75 Ma; @2012 Colorado Plateau Geosystems Inc.).

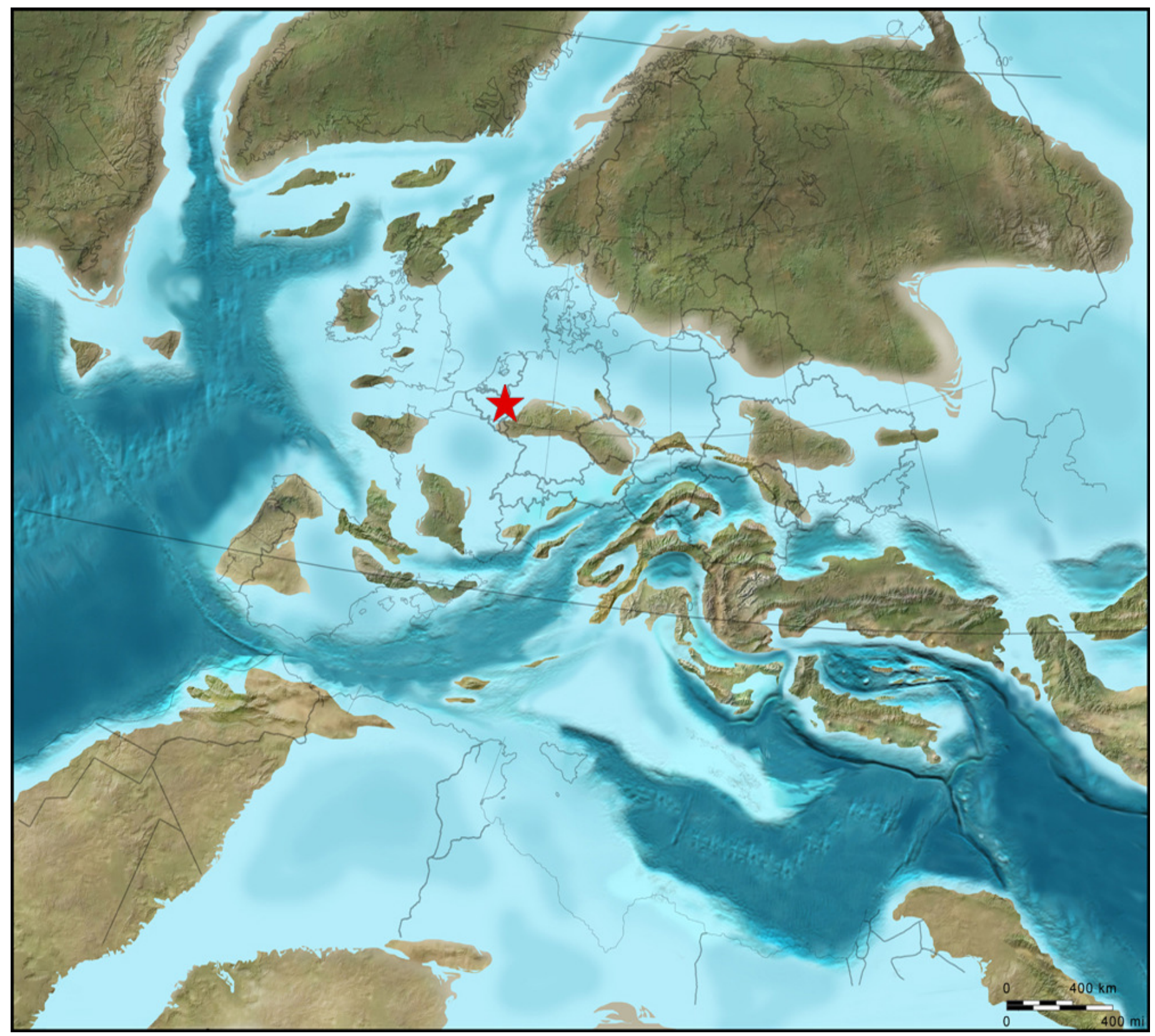




\section{Figure 5}

Ophiomitrella floorae n. sp., from the lower Gronsveld Member (Maastricht Formation; St Pieter and ENCl horizons) at the former ENCl-HeidelbergCement Group quarry, Maastricht, the Netherlands.

A-B: holotype (NHMM JJ 5104), dissociated proximal lateral arm plate in external (A) and internal (B) views; C: paratype (NHMM K 3387), articulated disc with basal arm segments in ventral view. Ophiomitrella granulosa Recent, as a close living relative of $O$. floorae n. sp. DE: proximal lateral arm plate (SMNH-121224) in external (D) and internal (E) views; F-G: complete individual (MNHNEcOs22429) in dorsal view (F) and with detail of ventral disc skeleton (G). Abbreviations: AOS: adoral shield; AS: arm spine; do: dorsal; LAP: lateral arm plate; MO: muscle opening; NO: nerve opening; OS: oral shield; pr: proximal; R: ridge; T: tooth; VA: vertebral articulation; VAP: ventral arm plate. Scale bars equal 0,25 mm in A-B and $D-E$, and $1 \mathrm{~mm}$ in $C$ and F-G. Scanning electron microscope images of Figs. F-G by Sabine Stöhr. 


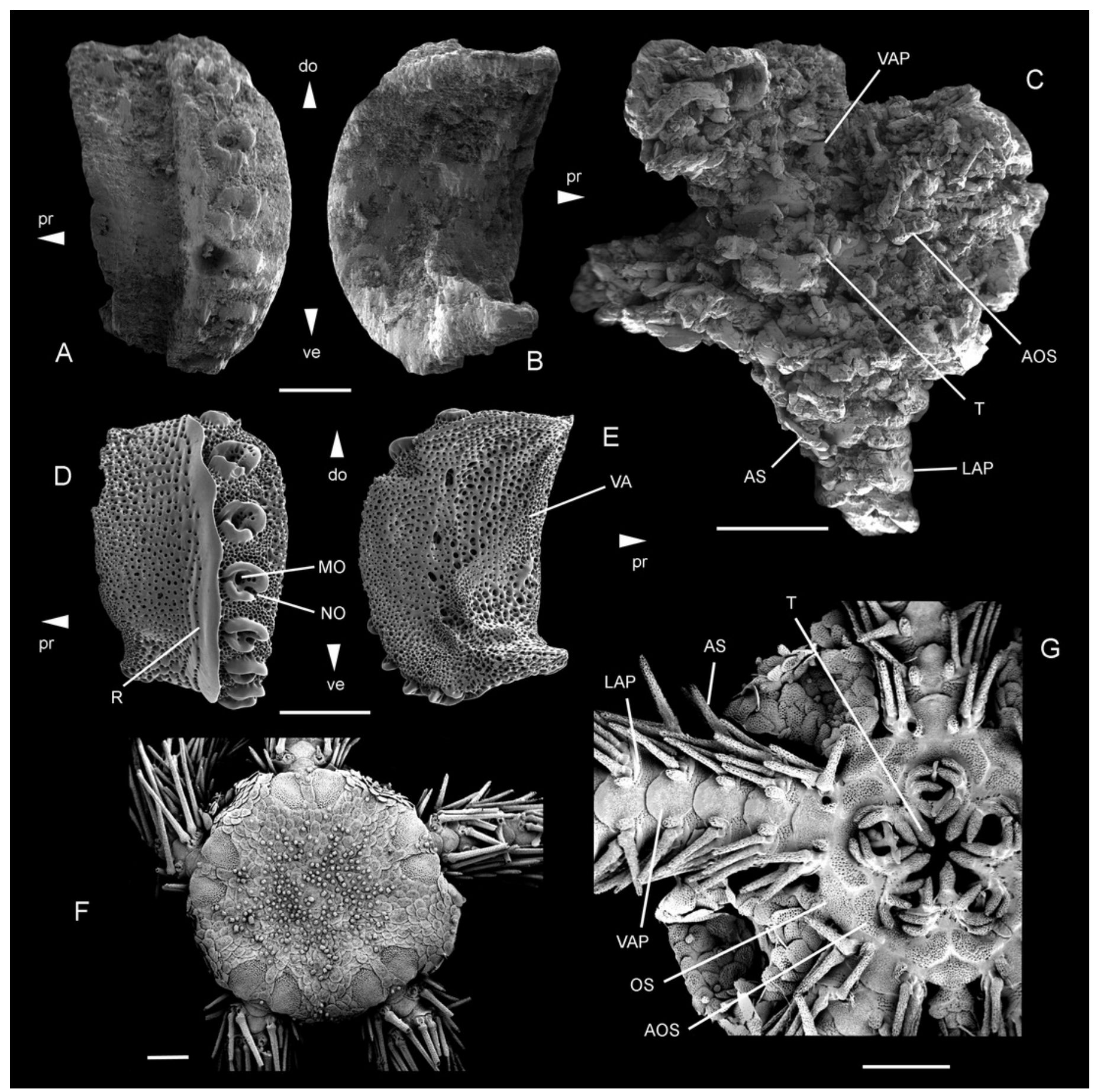




\section{Figure 6}

Ophiomitrella floorae n. sp., from the lower Gronsveld Member (Maastricht Formation; St Pieter and $\mathrm{ENCl}$ horizons) at the former ENCl-HeidelbergCement Group quarry, Maastricht, the Netherlands. Paratype (NHMM K 3387.

A: articulated skeleton before removal of the disc and proximal arm segments for scanning electron microscopy; B: detail of an arm in dorsal view. Abbreviations: DAP: dorsal arm plate; LAP: lateral arm plate. Scale bars equal $1 \mathrm{~mm}$. 


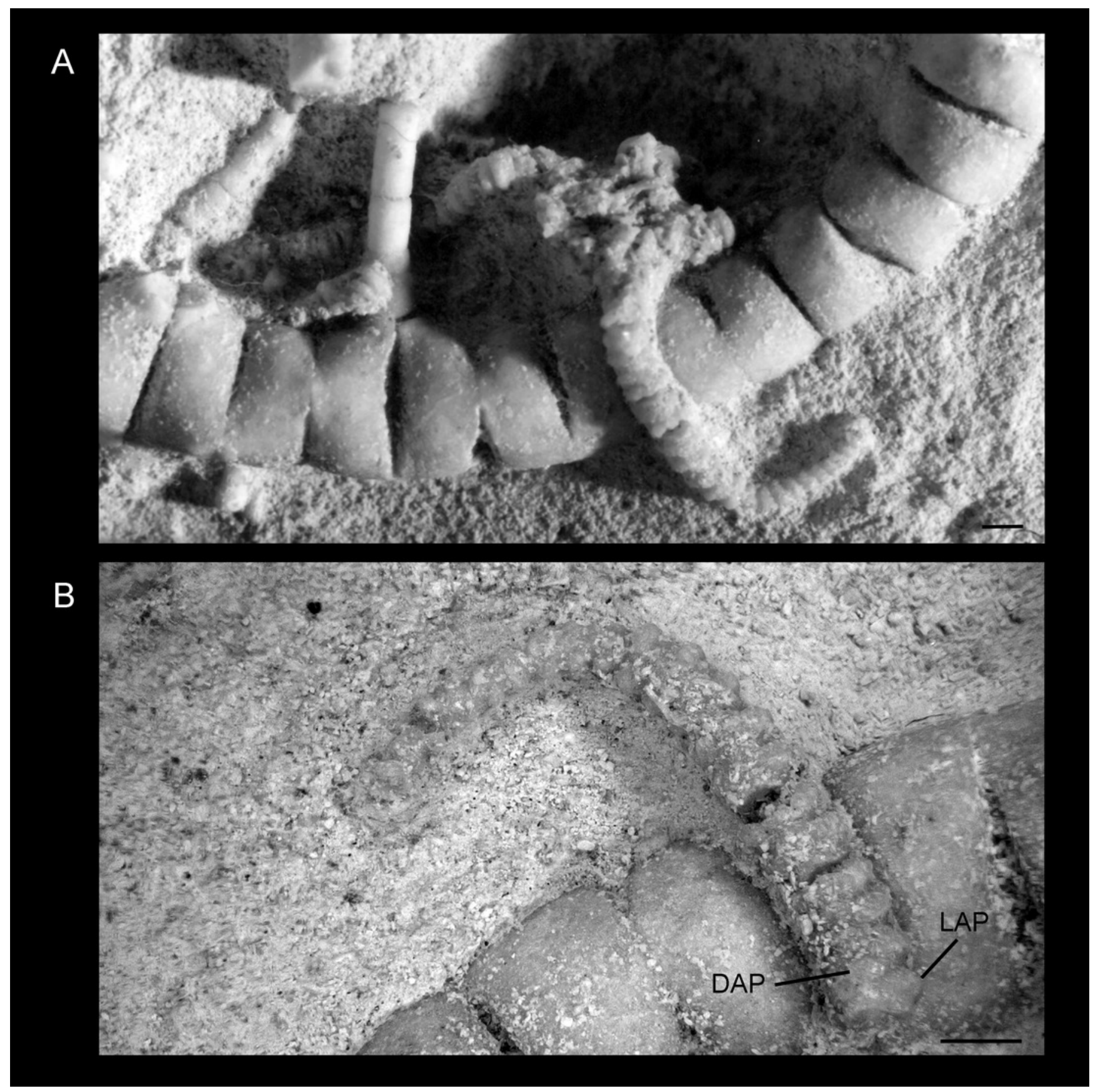

